\title{
Regional competitiveness in Poland: Creating an index
}

\author{
Urszula Bronisz • Wim Heijman • Andrzej Miszczuk
}

Accepted: 24 June 2008 / Published online: 19 July 2008

(C) The Author(s) 2008

\begin{abstract}
The present paper looks at the competitiveness from a regional perspective and examines the basic factor which have influence on this phenomenon. This article aims at evaluating Poland's regional competitive performance by constructing an overall index, which is composed in accordance with the Huggin's Institute approach. The purpose of the paper is both rank the 16 Polish regions (voivodships) according to their competitive position and see whether Huggin's approach was appropriate for measuring Polish competitiveness.

This article also aims to make a contribution to the debate surrounding the state of Polish regions competitiveness.
\end{abstract}

Keywords Competitiveness · Region · Index · Poland · Regional competitiveness

Zusammenfassung Der Beitrag betrachtet die Wettbewerbsfähigkeit von Regionen und bestimmt Faktoren, die darauf Einfluss haben. Es wird versucht, die Wettbewerbsfähigkeit der Regionen Polens mit einem zusammenfassenden Index zu messen, der dem Ansatz des Huggin's Instituts entspricht. Ziel dieses Artikels ist es,

U. Bronisz $(\square)$

Faculty of Political Science, Maria Curie-Skłodowska University, Plac Litewski 3, 20-080 Lublin,

Poland

e-mail: u-bronisz@tlen.pl

W. Heijman

Social Science, Economics of Consumers and Households, Wageningen University, P.O. Box 8130, 6700 Wageningen, The Netherlands

e-mail: wim.heijman@wur.nl

A. Miszczuk

Centre for European Regional And Local Studies, Warsaw University, Krakowskie Przedmieście 30, 00-927 Warszawa, Poland

e-mail: a.miszczuk@uw.edu.pl 
sowohl die 16 Regionen (Woiwodschaften) Polens nach deren Wettbewerbsfähigkeit zu ordnen als auch festzustellen, ob der Huggin's Ansatz geeignet ist, die Wettbewerbsfähigkeit polnischer Regionen zu messen. Außerdem soll dieser Artikel einen Beitrag zur Diskussion um die aktuelle Situation der Wettbewerbsfähigkeit der Regionen in Polen leisten.

\section{Introduction}

In economic life and beyond, competition is one of the fundamental sources of mobilization and creativity and therefore it has immense impact on regional development and growth. There are many different approaches concerning competitiveness. However, the overall competitiveness of nations or regions is difficult to measure because it is a complex function of different variables and factors, which importance varies over time. In today's global economy the primary spatial units which compete for the key economic assets are regions. They are consider as a places within which both knowledge and innovation are produced and diffused.

In 2004 Poland joined the European Union. It created for Polish regions a great opportunity to develop and become more competitive. Poland's membership in EU meant fully righted involvement in creating and taking advantages from the benefits of European policies. Participation in the EU regional policy gave Poland an opportunity to assist the lagging regions with the Union's resources and expertise (Grosse 2006, Hübner 2004, Czyzewski et al. 2003, Boeckhout 2004). By 2005, Poland had improved its competitive position, measured by GDP per capita in PPP terms, both toward the EU 15 countries and the new EU member state (Weresa 2006). In 19962006 Poland managed to decrease the distance to the average of the UE-25 (measured by GDP per capita) above 10 points per cent accomplishing 51,3\% this average (53,4\% average UE-27) (Żuber and Sudak 2007). But although, in the past few years we have noticed an enhancement in Polish economy we also observed increasing regional disparities. Some scientists and politicians noticed the disparity among regions in benefits from the access to European markets resulting in divergent economic growth results (Tomidajewicz 2003). Although there is a great support from the European Union for regional development, some regions are lagging behind in economic development. Poland's economically weakest regions are still at the tail end of Eurostat's list which illustrate inter-regional diversity in EU Member States.

This article aims at evaluating Poland's regional competitive performance from a comparative perspective. The purpose of this paper is to create an index concerning regional competitiveness in Poland which enables to establish the competitive position of the Polish regions. The 16 voivodships, which correspond to the EU NUTS II level, will be ranked according to their competitive position in accordance with Huggin's three-factor model of regional competitiveness. Furthermore, the competitiveness ranking we used enables us to compare different components of competitiveness. This allows for a more detailed overview of the indicators contributing to regional competitiveness. The aim of this paper is also to make a contribution to the debate surrounding the state of Polish regions competitiveness. The structure of the paper is as fallows. The first section outline the conceptual problems connected with the phe- 
nomenon of the competitiveness. The next part concerns the research framework, the approach applied in the paper. The following section focuses on creating index of Polish regional competitiveness. The final section provides a conclusion and reflections on the state of Polish regions.

\section{Competitiveness - Definitional problems}

Competitiveness has become a key priority for governments and regional authorities across Europe. It is apparent that competitiveness affects the development and the state of the economy. Although, the term "competitiveness" has been widely used by academics and policy practitioners, the concept in itself is rather complicated and easily misunderstood (Porter and Ketels 2003). The problem with defining competitiveness is similar with defining globalization. These terms have become very generic concepts, widely used but not defined precisely (Budd and Hirmis 2004). There are number of studies concerning competitiveness but there is no generally accepted definition of it in literature. In the European Competitiveness Report (EU 2006) competitiveness "is understood to mean a sustained rise in the standards of living of a nation or region and a level of involuntary unemployment as low as possible", whereas according to Dunning et al. (1998): "Competitiveness is a way of discussing the relative performance of economies in a benchmarking sense. It can help identify areas of the economy that are lagging behind but not the reason for those lags.”

According to the representatives of the World Economic Forum (WEF 2004): "competitiveness concerns adapting state economic institutions and economic structures to produce a growth visible in the international scale. The national economy is competitive in the international scale if its institutions and policy support rapid and stable economic growth". The Global Competitiveness Report provided by the World Economic Forum ranks countries according to certain key characteristic that affect and improve national competitiveness. The WEF pointed out 12 pillars of components that make a country competitive. Three most important pillars of competitiveness have been constructed to provide a shorter and less complex version of the global competitiveness index, namely the growth competitiveness index. This index consists of indices grouped together under: Technology and Innovation, Institutions and Macroeconomic structure. According to the representatives of the WEF these are the most important factors of national economies that ensure widely comprehended competitiveness.

A more concise definition on competitiveness is provided by the Organization for Economic Cooperation and Development (OECD). The OECD defines competitiveness as follows:

"The degree to which a country can, under free and fair market conditions, produce goods and services which meet the test of international markets, while simultaneously maintaining and expanding the real incomes of its people over the long term."

The competitive region is defined as "a region where the optimal structural relations between production factors, in changing conditions, are used to improve 
inhabitants, standard of living, attract new investors and encourage multi-purposed development of the area" (Ciechomski 2004).

Although, there are a number of studies concerning competitiveness in literature, we take up the definition formed by Robert Huggins Associates. They describe "competitiveness as referring to the capacity of an economy to attract and maintain firms with stable or rising market shares in an activity, while maintaining stable or increasing standards of living for those who participate in it” (Huggins 2004).

The competitiveness can be examined from two perspective. One of them take into account the potential level of competitiveness of nations or regions and this is so-called ex-ant approach. And there is also second method which is relying on the revealed effect of competitiveness. The competitiveness ranking created in this paper will use both perspectives and combine them into one approach. The carried out analysis of the regional competitiveness enable us to identify the most important factors and conditions which contribute to the economic development. The importance of the phenomenon of competitiveness is entrenched within economic policies both at national and regional level. That is why measuring and analyzing competitiveness become inherent factor of boosting economic performance of nations and regions.

\section{Research framework}

In order to present the performance of regional competitiveness in Poland we created an overall index which forms a composite picture of how Polish regions are performing and highlight the weaknesses, strengths and disparities that exist across Poland in terms of economic development and prosperity. We used the method worked out by Robert Huggins Associates. They produce the World Knowledge Competitiveness Index, which seeks to benchmark the globe's leading knowledge economy regions and the European Competitiveness Index which ranks cities and regions (Robert Huggins Associates 2004a, b). There are 16 voivodships in Poland and there are substantial economic disparities between them. In order to create an index concerning the overall picture of regional competitiveness and measure the level of competitiveness of Polish regions we followed the Huggins Institute approach (Huggins 2003). They identified the crucial variables required to asses the regional competitiveness and to rank regions according to the scores on these variables. They took into account the impact of three different categories: inputs, outputs and outcomes. The key input factors were: business density, knowledge based business and economic participation, although, there were many indicators underneath these subsets. Next, these variables were conceptualized as contributing to the output - productivity, measured GDP per capita. And finally, as the impact of these measures - the outcomes - the earnings and unemployment were given (see the Fig. 1). Than they ranked regions according to different assumptions on the importance of his indicators, checking for robustness of his factor model (Huggins and Davies 2006). This approach provided an overall picture of the regional level of competitiveness. In this paper data of essential measures were gathered from Eurostat and Central Statistical Office of Poland (GUS) sources. 


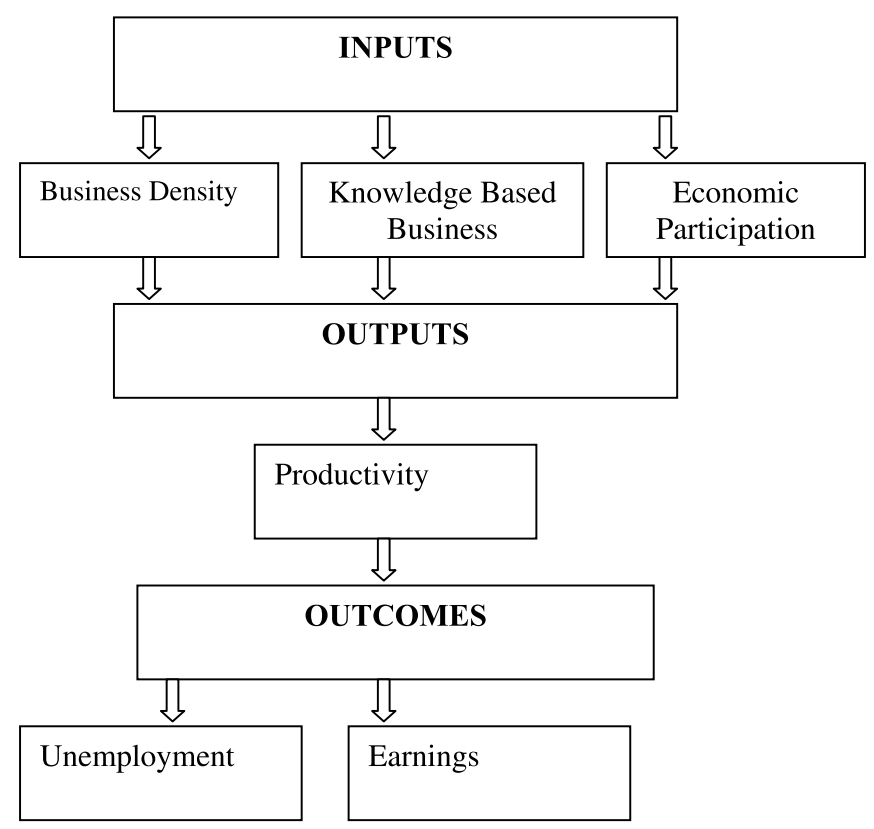

Fig. 1 Three-factor model for measuring local and regional competitiveness

The comparative analyses covered the evaluation of:

- GDP per capita,

- Average earnings (full time wages),

- Business density: the number of patent application, business units per million inhabitants in machinery and equipment manufacturing, post and telecommunications, research and development, the number of entities newly registered in public sector, and the number of entities newly registered in private sector,

- Knowledge based business: the number of patent applications per million inhabitants in: high tech, ICT, biotechnology, percent of business units of total em-

Table 1 Potential weighting scenarios for the composite index

\begin{tabular}{lcccccc}
\hline & $\begin{array}{c}\text { Business } \\
\text { density }\end{array}$ & $\begin{array}{c}\text { Knowledge } \\
\text { based } \\
\text { business }\end{array}$ & $\begin{array}{c}\text { Economic } \\
\text { participation }\end{array}$ & Productivity & Earnings & Unemployment \\
\hline 3-factor model & 1 & 1 & 1 & 3 & $1 \cdot 5$ & $1 \cdot 5$ \\
Equal weighting & 1 & 1 & 1 & 1 & 1 & 1 \\
Knowledge-intensive & 1 & 3 & 1 & 1 & 1 & 1 \\
Outcome-biased & 1 & 1 & 1 & 3 & 1 & 1 \\
Input-biased & 3 & 3 & 3 & 1 & 1 & 1 \\
Output-biased & 1 & 1 & 1 & 1 & 3 & 3 \\
Activity-led & 1 & 1 & 3 & 1 & 1 & 1 \\
Earnings-led & 1 & 1 & 1 & 1 & 3 & 1 \\
Business density-led & 3 & 1 & 1 & 1 & 1 & 1 \\
\hline
\end{tabular}

Sources: Huggins (2003) 


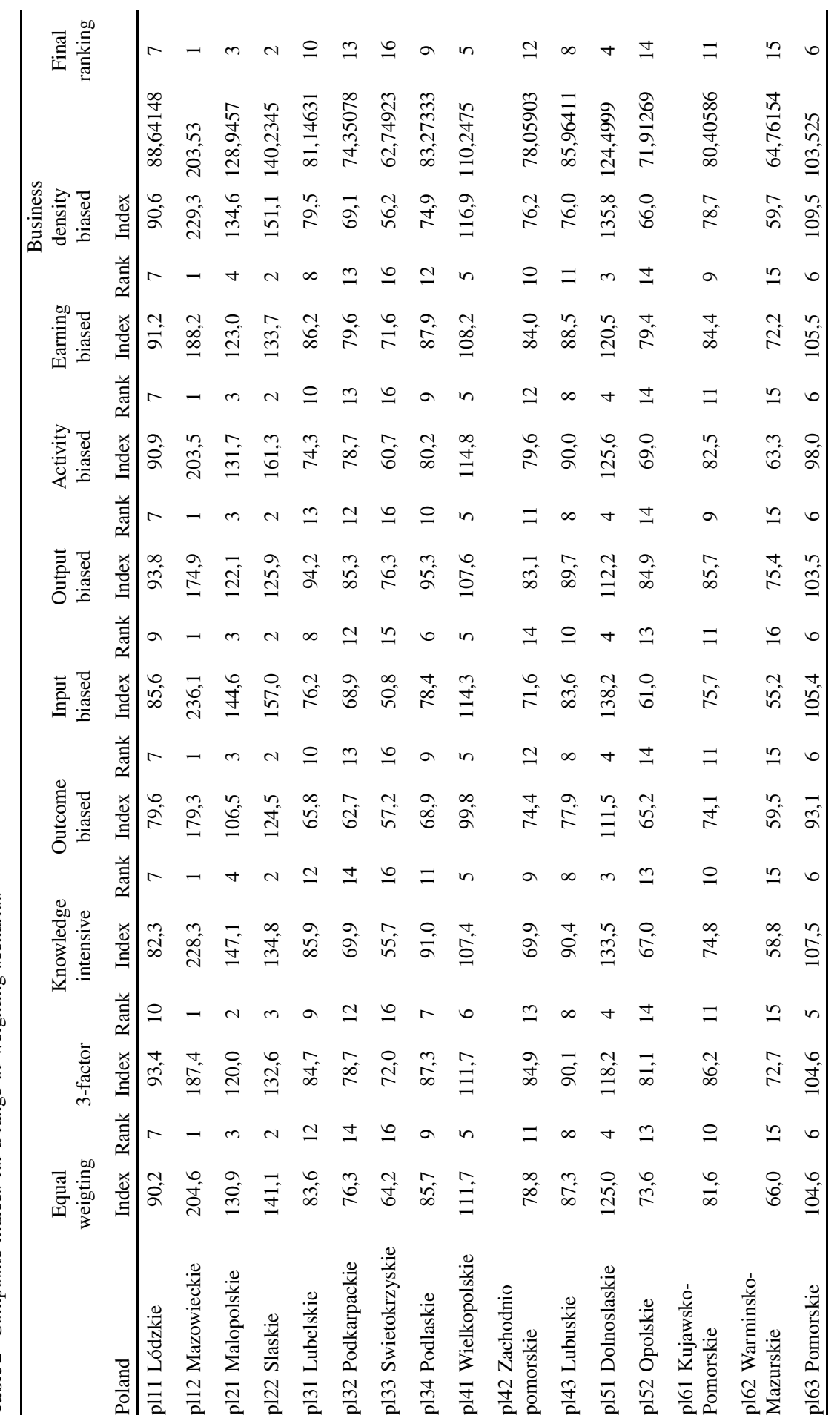




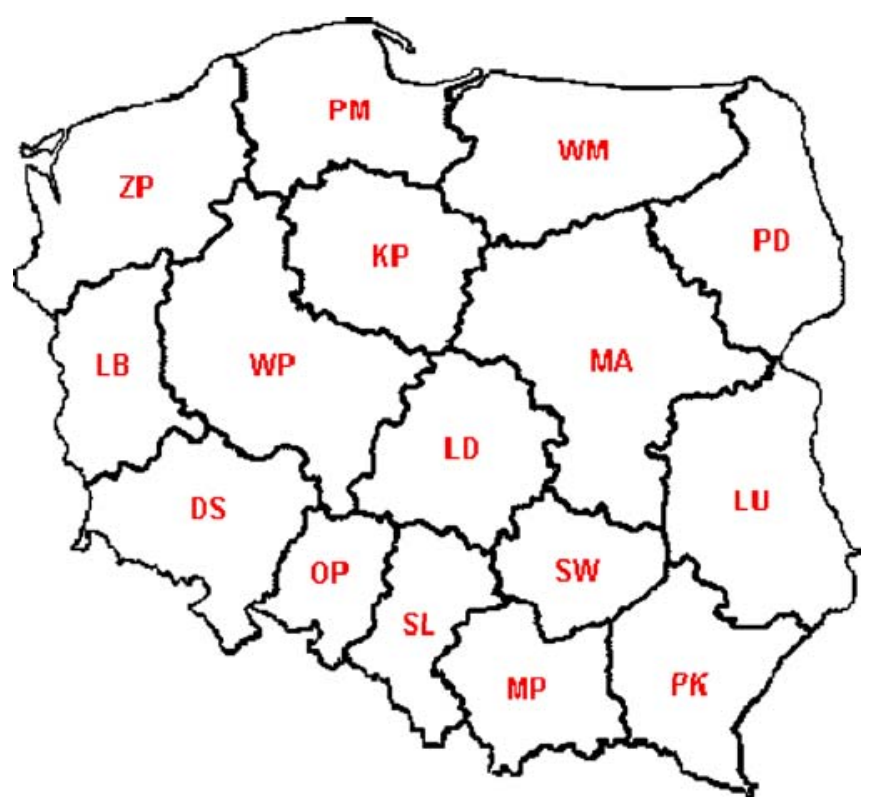

Fig. 2 The map of 16 Polish voivodships

Table 3 Ranking of regional competitiveness

\begin{tabular}{lcc}
\hline Rank & Region & Code \\
\hline 1 & Mazowieckie & MA \\
2 & Sląskie & SL \\
3 & Małopolskie & MP \\
4 & Dolnoślaskie & DS \\
5 & Wielkopolskie & WP \\
6 & Pomorskie & PM \\
7 & Łódzkie & LD \\
8 & Lubuskie & LB \\
9 & Podlaskie & PD \\
10 & Lubelskie & LU \\
11 & Kujawsko-Pomorskie & KP \\
12 & Zachodniopomorskie & ZP \\
13 & Podkarpackie & PK \\
14 & Opolskie & OP \\
15 & Warmińsko-Mazurskie & WM \\
16 & Świętokrzyskie & SW \\
\hline
\end{tabular}

ployment in total knowledge intensive services, percent of business units of total employment in high and medium tech manufacturing, expenditures on innovation activities, expenditures on research development activity,

- Economic participation: the number of upper secondary students, vocational educational students, tertiary students (academic), tertiary students (occupations), economic activity rate,

- Unemployment,

- Earnings. 
The 16 Polish regions (see the Fig. 2) were ranked according to their scores on each indices. Then was assessed the importance of business density, knowledge based business, economic participation, productivity, earnings and unemployment on the basis of the scenarios created by Huggins Institute (see the Table 1). And afterward we achieved the final $\mathrm{f}$ results of competitiveness of Polish 16 voivodships (see the Table 2 and Table 3). In Huggin's article UK competitiveness rankings are created on both the regional and local level to compare the performance of the regions (Huggins 2003). Based upon factor analysis Huggins proposes a weighing system for different components of competitiveness and test the robustness of the results with different weighing systems.

In this paper we could consider only the regional dimension, data concerning the communes from local level was not available. The number of cases in this research $(N=16)$ did not allow for a detailed statistical analysis. Here we deviated from Huggins' approach by taking the results of his factor analysis on the regions and localities in England and compared the ranking of this weighing systems to the other proposed weighing systems for the competitiveness of regions and applied this on the Polish regions. We tried to use this approach for the 16 voivodships in Poland to first of all rank the regions according to their competitive position and secondly to see whether Huggins approach can be used to measure Polish competitiveness as well.

\section{Index of regional competitiveness}

The regional competitiveness specified in the created ranking means competitiveness resulting from objective conditions. The most competitive Polish region is undoubtedly the Mazowieckie voivodship. It took the first position regardless of the scenarios taken into account. It is a capital region where significant concentration of economic activity occurs in the political center of the country. In the top head of ranking we can find also Ślaskie, Małopolskie and Dolnoślaskie voivodships. These are the regions that have the ability to attract skilled, creative and innovative people, to provide high quality cultural facilities; and to encourage the development of social networks and institutional arrangements that share a common commitment to regional prosperity. These are also regions that have the highest density of firms, the most knowledge-intensive firms and the highest level of economic participation. Furthermore, relatively developed infrastructure and low labour costs combines with labour force skills, all contributed to stimulate markets and encourage investment into Mazowieckie, Małopolskie, Śląskie or Dolnośląskie regions (Gorzelak 2000). In these regions new firms stimulate competitiveness via market selection and competitive pressures, by forcing less efficient incumbents to exit or to improve their productivity this way, both the creation and destruction of firms may improve competitiveness (Bosma et al. 2006). The more middle-ranked regions have more fluidity in their rankings.

The most economically disadvantaged regions in Poland are located at the eastern periphery of the country, namely Świętokrzyskie, Warmińsko - Mazurskie, and Podkarpackie voivodships. The poor economic performance of these regions can be 
caused by the predominance of agriculture in regional economy and also because of the comparatively unfavorable geographical location of those regions. They border with less economically developed countries like Belarus, Ukraine and Russia what makes difficult new economic initiatives and limits the opportunities for fruitful transborder cooperation (Sadowska-Snarska 2002). It is widely acknowledged that less developed regions face particular challenges in promoting and developing innovation potential (Boeckhout 2004). The problem of these regions is an absence of basis innovative capacity in business what is especially significant in such areas as Podlaskie, Warmińsko-Mazurskie, Podkarpackie and Opolskie voivodships. That is why here should be put more emphasis on mobile investment and on creating environments where high-quality business can start and succeed (Turok 2004).

The standard measure of regional success is GDP per capita. The most affluent voivodship in Poland with GDP per capita of $164 \%$ of the national average is Mazowieckie. Among the other regions, above average GDP per capita have also Ślaskie, Wielkopolskie, Dolnośląskie and Pomorskie. Furthermore GDP growth in Polish regions is characterized by high regional concentration, namely Mazowieckie, Śląskie and Wielkopolskie generate one fourth of the total gross domestic products. With regard to the unemployment, in $200517.7 \%$ of the active labour force in Poland was unemployed. Recent developments on the Polish labour market justify some optimism, but a heavy structural unemployment component makes rapid improvement unlikely (Narożny 2006). Ideally, both employment growth and productivity growth should go together (Kitson et al. 2004): increasing productivity causes an improved competitive position, which leads to higher demands of the goods and services produced, which in turn leads to an increased demand for labour inputs (Bosma et al. 2006).

\section{Conclusion}

In the world of "performance indicators and ranking" it is apparent that regions should be compared against each other in terms of their economic position. The present article looked at competitiveness from a regional perspective and has attempted to conceptualize regional competitiveness by combining some data, namely inputs, outputs and outcomes into one global index. It allowed to measure the state of Polish 16 regions and ranked them according the final result. The Huggins approach concerning competitiveness was applied in order to create the ranking of competitiveness of Polish regions consisted of many different components. The ranking enabled both the examination of the performance of regions and comparison the state of Polish voivodships.

Poland represents a country with growing regional disparities which is an unavoidable consequence of the process of transformation and economic growth. However the differences in economic development of the Polish voivodships will not fade in the next few years, the gaps between the most and least rapidly developing regions are to widen (Sadowski 2005). The low level of ability of the economy to introduce innovations, observed in almost the whole country, has a great impact on the slow course of restructuring processes among enterprises as well as on structural changes. Therefore the basis of the country's competitive advantage has to be redefined (Weresa 
2006). Investment in research and development are crucial, furthermore the engines for growth are improvements in both technology and human capital. It is worth to remember that improvement in competitiveness is not a linear process, but the enhancement of competitiveness requires progress on multiple areas simultaneously.

Nowadays, regional competitiveness is an outcome of economic performance, based on various factors. The level of regional competitiveness depends mainly on the quality of human capital, innovations, knowledge and efficiency of local economy and is determined by long-term perspectives of development.

Open Access This article is distributed under the terms of the Creative Commons Attribution Noncommercial License which permits any noncommercial use, distribution, and reproduction in any medium, provided the original author(s) and source are credited.

\section{References}

Boeckhout S (2004) Regional innovation strategies in Poland: Lessons and Recommendations. ECORYS Research and Consulting, Rotterdam

Bosma N, Stam E, Schutjens V (2006) Creative destruction and regional competitiveness: Scientific analysis of entrepreneurship and SMEs. SCALES, Zoetermeer

Budd L, Hirmis AK (2004) Conceptual framework for regional competitiveness. Reg Stud 38(9):10151028

Czyżewski AB, Orłowski WM, Zienkowski L (2003) Macroeconomic costs and benefits of Poland's membership in the EU: Analysis and evaluation in cost and benefits of Poland's membership in the European Union. Centrum Europejskie Natolin, Warsaw

Dunning J, Bannerman E, Lundan SM (1998) Competitiveness and industrial policy in Northern Ireland. Monograph 5, March. Northern Ireland Research Council, Belfast

EU (2006) European competitiveness Report 2006. Commission Staff Working Paper SEC

European Commission (2004) A new partnership for cohesion: Convergence, competitiveness and cooperation. European Commission, Brussels

Gorzelak G (2000) Poland. In: Bachtler J, Downes R, Gorzelak G (eds) Transition, cohesion and regional policy in central and eastern europe. Ashgate Publishers, Aldershot, pp 125-154

Grosse TG (2006) Euro-commentary: An evaluation of the regional policy system in Poland: Challenges and threats emerging from participation in the EU's cohesion policy. Eur Urban Reg Stud 13:151165

Huggins R (2003) Debates and surveys creating a UK competitiveness index: Regional and local benchmarking, Reg Stud 37(1):89-96

Huggins R, Davies W (2006) European Competitiveness Index 2006-07. Robert Huggins Associates Ltd, United Kingdom

Hübner D (2004) Impact of the membership in the European Union on economic growth in Poland. Transformation, Integration and Globalization Economic Research. No 51, Warsaw

Kitson M, Martin R, Tyler P (2004) Regional competitiveness: An elusive yet key concept? Reg Stud 38:991-999

Lobatch AI (2004) EU membership and growing regional disparities: Poland's strategy options to optimize structural transfers from the union. Paper presented at the twelfth NISPAcee annual conference "Central and Eastern European countries inside and outside the European Union: avoiding a new divide", Vilnius, Lithuania, May 13-15 2004

Martin RL (2003) A study on the factors of regional competitiveness. A draft final report for the European Commission Directorate-General Regional Policy. ECORYS-NEI, Rotterdam

Ministry of Regional Development Poland (2004) Sectoral operational programme improvement of the competitiveness of enterprises years 2004-2006. Ministry of the Economy Labour and Social Policy, Warsaw

Narożny M (2006) High unemployment in Poland - not only a labour market problem. Economic analysis from the European Commission's Directorate-General for Economic and Financial Affairs, vol III, Issue 6. Office for official Publications of the European Communities, Luxembourg 
Porter ME (2000) Location, competition and economic development: Local clusters in a global economy. Econ Dev Q 14(1):15-34

Porter ME (2003) The economic performance of regions. Reg Stud 37(6-7):549-578

Porter ME, Ketels CHM (2003) UK competitiveness: Moving to the next stage, DTI Economic Paper 3. Department of Trade and Industry, London

Robert Huggins Associates (2004a) World knowledge competitiveness index. Robert Huggins Associates, Pontypridd

Robert Huggins Associates (2004b) European competitiveness index. Robert Huggins Associates, Pontypridd

Sadowska-Snarska S (2002) Struktura Gospodarki a Poziom Rozwoju Regionów Wschodniej Polski (Economic structure and the level of development of eastern polish regions). In: Sadowska-Snarska S (ed) Problemu Rozwoju Przygranicznych Regionów Wschodniej Polski (Problems of developpment of border regions in eastern Poland). Białystok School of Economics, Białystok, pp 131-165

Sadowski M (2005) Poland: Regional economic forecasts 2005-2008. PMR, Kraków

Tomidajewicz JJ (2003) Sektory Wrażliwe na Proces Integracji z UE a Problemy Polityki Gospodarczej w Procesie Akcesyjnym (Sectors Vulnerable to the Process of Poland's Integration into the European Union and the Problems of Economic Policy in the process of Poland's accession to the EU). In: Tomidajewicz JJ (ed) Polityka Gospodarcza w Procesie Akcesji Polski do UE (Economic policy in the process of Poland's accesion to the EU). Wydawnictwo Akademii Ekonomicznej, Poznan

Turok I (2004) Cities, regions and competitiveness. Reg Stud 38(9):1069-1083

WEF (2004) The global competitiveness report 2004-2005. Palgrave Macmillan, Hampshire, England

Weresa MA (2006) Science, technology and innovation. In: Weresa MA (ed) Poland competitiveness report 2006 the role of innovation. World Economy Research Institute Warsow School of Economics, Warsaw

Żuber P, Sudak S (eds) (2007) Ocena postepów Polski w zakresie spójnosci z Unia Europejska (The evaluation of development Polish cohesion policy with the European Union). Ministerstwo Rozwoju Regionalnego, Warszawa 2007 